ANADOLU, J. of AARI

ISSN: 1300-0225 (Print)

E-ISSN: 2667-6087 (Online)

2021, 31 (2): 212-225

DOI: $10.18615 /$ anadolu.1033597

\title{
Peach Production and Foreign Trade of Turkey: Current Situation, Forecasting and Analysis of Competitiveness
}

\author{
Alamettin BAYAV $V^{*}\left(\mathbb{O} \quad\right.$ Melike ÇETINBAŞ ${ }^{2}$ \\ ${ }^{1 *}$ Isparta University of Applied Sciences, Faculty of Agriculture, Department of Agricultural Economics, \\ Isparta/TURKEY \\ ${ }^{2}$ Fruit Research Institute, Ĕ̈̈irdir, Isparta/TURKEY \\ ${ }^{I *}$ https://orcid.org/0000-0002-8093-2988 $\quad{ }^{2}$ https://orcid.org/0000-0002-2755-2396 \\ *Corresponding author (Sorumlu yazar): alamettinbayav@hotmail.com \\ Received (Geliş tarihi): 18.04.2021Ａccepted (Kabul tarihi): 06.08.2021
}

\begin{abstract}
In this study, changes in peach-nectarine (Prunus persica L.) production and trade in the world and Turkey have been evaluated considering developments in the last decade. Turkey's production and export volumes for the next three years were also estimated, and competitiveness analysis was performed for the major exporting countries. According to 2010-2019 data, it was determined that there were significant changes in peach-nectarine production, production areas, and productivity in the world. Production and export forecasting was examined with the ARIMA model, which is the Box-Jenkins method. By using 50-year data covering 1971-2020, ARIMA (1,1,0) was the best model in production and ARIMA $(0,1,2)$ in exports. Estimates indicated that Turkey's export and production in 2023 would be 893.575 and 157.343 tons, respectively. To determine competitiveness, Balassa's revealed comparative advantage and Vollrath's relative export advantage index, relative import penetration index, relative trade advantage index, and revealed competitiveness were used. For this purpose, important exporting countries such as Spain, Greece, Italy, China, Chile, USA, Jordan, Uzbekistan and the Netherlands were examined. Considering the index values calculated for the period covering the years 2010-2019, it has been determined that Turkey has a comparative advantage in peach-nectarine exports. Spain, Uzbekistan, Greece, Jordan, and Chile attracted attention as other countries with comparative advantage. Besides protecting existing markets, speeding up the search for new markets is very important to maintain the comparative advantage gained by Turkey.
\end{abstract}

Keywords: Prunus persica L., production, export, ARIMA, forecasting models, competitiveness, Turkey.

\section{Türkiye Şeftali-Nektarin Üretimi ve Dış Ticareti: Mevcut Durum, Öngörüller ve Rekabet Gücü Analizi}

ÖZ: Bu çalı̧̧mada, son on yıldaki gelişmeler dikkate alınarak dünya ve Türkiye şeftali-nektarin (Prunus persica L.) üretim ve ticaretindeki değişimler değerlendirilmiş, gelecek üç yıla ait Türkiye'nin üretim ve ihracat miktarları tahmin edilmiş ve önemli ihracatçı ülkelere ait rekabet gücü analizi yapılmıştır. 2010-2019 yıllarına ait veriler dikkate alındığında dünyada şeftalinektarin üretim miktarl, üretim alanlarl ve verimliğinde önemli değişimler olduğu tespit edilmiştir. Üretim ve ihracat tahmini Box-Jenkins metodu olan ARIMA modeli ile incelenmiştir. 1971-2020 yıllarını kapsayan 50 yıllık veriler kullanilarak üretimde en iyi modelin ARIMA (1,1,0), ihracatta ise ARIMA $(0,1,2)$ olduğu tespit edilmişstir. Tahminler 2023 yllinda Türkiye üretiminin 893,575 tona, ihracatının 157,343 tona yükseleceğini göstermektedir. Rekabet gücünün belirlenebilmesi için Balassa'nın açıklanmış karşılaştırmalı üstünlükler endeksi ve Vollrath'ın göreli ihracat avantajı endeksi, göreli ithalat avantajı endeksi, göreli ticaret avantajı endeksi ve açıklanmış rekabetçilik endeksi kullanılmıştır. Bu amaçla önemli ihracatçı ülkeler olan İspanya, Yunanistan, İtalya, Çin, Şili, ABD, Ürdün, Özbekistan ve Hollanda incelenmiştir. 2010-2019 yıllarını kapsayan periyotta hesaplanan endeks değerleri dikkate alındığında Türkiye’nin şeftali-nektarin ihracatında karşılaştırmalı üstünlüğe sahip olduğu belirlenmiştir. Ispanya, Özbekistan, Yunanistan, Ürdün ve Şili karşılaştırmalı üstünlüğe sahip diğer ülkeler olarak dikkati çekmiştir. Türkiye'nin elde ettiği bu karşılaştırmalı üstünlügünü koruyabilmesi için mevcut pazarların korunması yanında, yeni pazar arayışlarına hız verilmesi oldukça önemlidir.

Anahtar Kelimeler: Prunus persica L., üretim, ihracat, ARIMA, tahmin modelleri, rekabet gücü, Türkiye. 


\section{INTRODUCTION}

Supplying the nutritional needs of the increasing population, economic and sustainable development are the most important issues that are studied today. From this point of view, the agricultural sector plays an important role in all countries' nutrition and development. The agricultural sector is economically the primary sector in the world, and within this, fresh fruit and vegetable production has an important value-added position. Fruit production in the world is 883 million tons on an area of approximately 65.3 million hectares. With a production of 117 million tons, bananas are the most cultivated product in the world. After bananas, the most produced fruits are respectively apples (87 million tons), oranges (79 million tons), grapes ( 77 million tons), and mangos (56 million tons) (Anonymous, 2021a). There have been rapid developments in fruit production, consumption, and storage since the 1950s. Factors affecting these rapid developments are expanding transportation networks and cold storage, extended storage periods, processing and other methods to transform the fruits into non-spoilable forms, improvement in production methods, and increasing focus on agricultural innovations (Gül and Akpınar, 2006).

Among fruit species, peaches and nectarines have a world production share of $2.9 \%$ (Anonymous, 2021a). Peach and nectarine production is developing rapidly, as is the case with other fruit species. Peach and nectarine cultivation is carried out in many countries located in warm-temperate and temperate regions of the temperate climate zone. The ability of varieties to adapt to different ecologies; early fruiting; having fruit rich in organic and mineral substances with unique, beautiful color, odor, and excellent taste; and the ability to produce over a wide period are important factors in the development of peach production. In addition, peach is a preferred fruit species due to its use as fruit juice concentrate, pulp, jam, marmalade, and dried peach in addition to fresh consumption. With the contribution of studies for increasing yield and fruit quality in recent years, peach and nectarine production and trade have increased in the world and Turkey. All these developments have caused an increase in countries' efforts to get more shares from the global peachnectarine market.

In order to have a say in the international market in peach-nectarine trade, it is necessary to know the competitiveness of countries. No study that analyzes Turkey's peach-nectarine competitiveness has been found in the literature. Linghong et al. (2015) proposed a new algorithm to determine the competitiveness of peach in the Hebei province of China. In that study, the Analytical Hierarchy Process method was used with the data of 20012010. Berk et al. (2016) evaluated 22 products that were top in Turkey's exports, including peach, between 2004 and 2015 and carried out a competitiveness analysis. Competitiveness indices were calculated for Spain, Netherlands, USA, Mexico, China, Chile, Italy, Turkey, South Africa, and France, which were leaders in the trade of these products. The competitiveness of Turkey's fresh fruit and vegetable sector in international trade was determined and evaluated with the calculated indices. The results showed that Turkey had a significant comparative advantage in the export of fresh fruits and vegetables in global markets. Numerous studies have been conducted to analyze the competitiveness of different agricultural products (Ketenci and Bayramoğlu, 2018; Özdemir and Kösekahyaoğlu, 2018; Çelik et al., 2019; Balc1 and Giray, 2020; Shalbuzov et al., 2020).

In this study, based on world peach-nectarine production and trade, Turkey's rank in the world in this sector was evaluated, and projections were made for the next three years. From 2010 to 2019, the top ten leading export countries' (Turkey, Spain, China, Italy, USA, Chile, Greece, Jordan, Uzbekistan, and the Netherlands) competitiveness was identified and compared with Turkey's competitiveness.

\section{MATERIAL and METHOD}

This study's main material was composed of the production, import, and export values and quantities obtained from the International Trade Center (ITC-TRADE MAP), the United Nations 
Food and Agriculture Organization (FAO), and the Turkish Statistical Institute (TURKSTAT) database. Fifty year data (1971-2020) were used with the Box-Jenkins method for production and export forecasts. Balassa and Vollrath's comparative advantage indices were used to determine the competitive situation in the peach and nectarine sectors. For calculating the indices coefficients, 10year trade data covering 2010-2019 obtained from the ITC database of peach and nectarine with the Customs Tariff Statistics Position (GTIP) number 080930 was used. Also in this study, the peachnectarine production potential of Turkey and the world, in general, was assessed. Within this framework, production, production area, yield, export, and import values of the last 10 years (20102019) were used, simple indices were calculated, and the findings obtained were interpreted.

\section{Box-Jenkins method}

Time series data are generated by ordering data belonging to a feature. The purpose of using time series is to make forecasts for the future using the past and current data of a feature and to make plans in the light of these forecasts. The Box-Jenkins approach was used in this study, as in many studies (Özer and İlkdoğan, 2013; Berk and Uçum, 2016; Kaygisız and Sezgin, 2017; Topuz et al., 2018; Kurt and Karayılmazlar, 2019; Küçükoflaz et al., 2019), for peach-nectarine production and export forecasts.

The Box-Jenkins method, which forecasts for any period of the series, taking into account the past observation values and error terms, can be used in univariate time series (Özmen, 1986). In cases where the variance, covariance, and mean of the time series do not change with time, the time series is emphasized as stationary. In this case, one of the appropriate autoregressive (AR), moving average (MA), and autoregressive moving average (ARMA) models are used. However, in reality, most of the time series is non-stationarity since it is a stochastic process. When data are non-stationary, autoregressive integrated moving average (ARIMA) models are used (Sevüktekin ve Nargeleçekenler, 2010).
A non-stationary time series must be stationary to employ the Box-Jenkins method (Özmen, 1986). For this purpose, the Augmented Dickey-Fuller (ADF) unit root test, developed by Dickey and Fuller (1981), was applied to the data. The time series containing unit-roots was made stationary by determining the difference. The ARIMA model is represented as ARIMA $(p, d, q)$ if $p$ is the degree of the autoregression parameter $\Phi(\mathrm{B}), \mathrm{q}$ is the degree of the moving average parameter $\Phi(\mathrm{B})$, and the difference is made d times, according to Box and Jenkins (1976).

A general ARIMA (p, d, q) model is expressed as follows.

$$
\begin{aligned}
& \mathrm{W}_{\mathrm{t}}=\Phi_{1} \mathrm{~W}_{\mathrm{t}-1}+\Phi_{2} \mathrm{~W}_{\mathrm{t}-2}+\ldots+\mathrm{e}_{\mathrm{t}}-\theta_{1} \mathrm{e}_{\mathrm{t}-1}- \\
& \theta_{2} \mathrm{e}_{\mathrm{t}-2}-\ldots-\theta_{\mathrm{q}} \mathrm{e}_{\mathrm{t}-\mathrm{q}}
\end{aligned}
$$

$\mathrm{W}_{\mathrm{t}}$ is the value of the $\mathrm{Y}_{t}$ process with the degree difference. The AR, MA, and ARMA models are included in the preceding equation if the series is stationary as the initial values, that is, $\mathrm{d}=0$ (Box and Jenkins, 1976).

\section{Competitiveness analysis}

Balassa's revealed comparative advantage (RCA) (Balassa, 1965) and Vollrath's relative export advantage index (RXA), relative import penetration index (RMP), relative trade advantage index (RTA), and revealed competitiveness (RC) (Vollrath, 1991) were employed in the study's competitiveness analysis of the peach-nectarine sector.

The Revealed Comparative Advantage Index of Balassa is calculated as follows.

$R C A_{j}^{i}=\frac{x_{j}^{i} / \sum x^{i}}{\sum x_{j}^{w} / \sum x^{w}}$

In Equation 2;

Where $R C A_{j}^{i}$ refers to the Revealed Comparative Advantage Index of the country $\mathrm{i}$ in product $\mathrm{j} ; x_{j}^{i}$ refers to the export value of product $j$ of country $i$; $\Sigma x^{i}$ refers to the total export value of country $\mathrm{i}$; $\Sigma x_{j}^{w}$ refers to the total export value of the world product $\mathrm{j} ; \Sigma x^{w}$ refers to the world total export value. 
In Equation 2, if the RCA is greater than 1, it means that country $i$ has a comparative advantage in industry $\mathrm{j}$ because this sector is more important for the country $\mathrm{i}$ exports than the export of reference countries (Hinloopen and Marrewijk, 2001). Hinloopen and Marrewijk (2001) divided RCA into four classes in their study. Countries with RCA values between 0 and 1 have no comparative advantage. The other three groups of countries with RCA values of 1-2, 2-4, and greater than 4 are categorized as having a weak comparative advantage, a medium comparative advantage, and a strong comparative advantage. In the study Hinloopen and Marrewijk (2001) technique was used to interpret RCA values.

The indices developed by Vollrath are given below.

Relative Export Advantage Index (RXA):

$R X A_{j}^{i}=\frac{x_{j}^{i} / \sum x^{i}}{\sum x_{j}^{w} / \sum x^{w}}$

$R X A_{j}^{i}$ denotes the Relative Export Advantage Index of country $\mathrm{i}$ in product $\mathrm{j} ; x_{j}^{i}$ denotes the export value of product $\mathrm{j}$ of country $\mathrm{i} ; \Sigma x^{i}$ denotes the total export value of country i; $\Sigma x_{j}^{w}$ denotes the total export value of the world product $\mathrm{j} ; \Sigma x^{w}$ denotes the world total export value.

The RXA index value is quite similar to the RCA index value. The difference between RCA and RXA is that the country's export values considered in RXA are calculated by subtracting the total export value. If $\mathrm{RXA}>1$, it is interpreted that the sector's export performance is greater than the world export performance, while RXA $<1$ is interpreted as that country's export performance is lower than the world export performance.

Relative Import Penetration Index (RMP):

$R M P_{j}^{i}=\frac{M_{j}^{i} / \sum M^{i}}{\sum M_{j}^{w} / \sum M^{w}}$

$R M P_{j}^{i}$ is the Relative Import Penetration Index of country i in product $\mathrm{j} ; M_{j}^{i} \mathrm{i}$ is the import value of product $\mathrm{j}$ of country $\mathrm{i} ; \Sigma M^{i}$ is the total import value of country i; $\Sigma M_{j}^{w}$ is the total export value of the world product $\mathrm{j} ; \Sigma M^{w}$ is the world total import value.

If $\mathrm{RMP}>1$, the country has a relative disadvantage in the relevant sector, while when RMP $<1$, the country has a relative advantage in the relevant sector.

Relative Trade Advantage Index (RTA):

Subtracting the RMP index value from the RXA index value yields the RTA index value. It is formulated as follows.

$R T A_{j}^{i}=R X A_{j}^{i}-R M P_{j}^{i}$

If the difference is positive, the country has a competitive advantage in the relevant sector; if the difference is negative, the country does not have a competitive advantage.

Revealed Competitiveness (RC):

The following equation calculates RC.

$R C_{j}^{i}=\ln R X A_{j}^{i}-\ln R M P_{j}^{i}$

A positive $\mathrm{RC}$ value indicates comparative advantage; a negative result indicates comparative disadvantage.

\section{RESULTS and DISCUSSION}

\section{Improvements in world peach-nectarine production}

World peach-nectarine production increased by approximately $25 \%$ in 2010-2019 (Table 1). This increase in production can be associated with establishing new peach-nectarine orchards and increasing yield per unit area to meet the increasing population demand. China ranked first in the world production of peach-nectarine in 2019 with a share of $61.5 \%$. Spain (6\%), Italy (4.7\%), Greece (3.6\%), Turkey $(3.2 \%)$, the USA $(2.9 \%)$, Iran $(2.3 \%)$, Egypt (1.4\%), Chile (1.3\%) and Argentina (0.8\%) follow China (Anonymous, 2021a).

There were differences in these countries' production changes, which were leaders in peachnectarine production, in 2010-2019. In Turkey, China, Spain, Greece, Iran, and Egypt, production 
increased, while in Italy, the USA, Chile, and Argentina production decreased (Table 1). China and Turkey were the countries where most of the proportional production increased in 2010-2019. In Turkey, compared to 2010, production increased nearly 54\% in 2019.

In Table 2, developments in peach-nectarine production areas are given for the periods 20102019. Table 2 shows that other major producing countries reduced the production area except for China and Turkey. In general, peach-nectarine production areas decreased in the world. As a result of the increase in research activities in peach-nectarine in recent years, the development of high-density planting systems and modern production techniques has caused an increase in yield despite the narrowing of production areas. Since the rate of increase in production in Turkey and China is higher than the rate of increase in the production area, it is also possible to share the same views for these two countries.

Table 1. Production quantities and changes of major peach-nectarine producing countries.

Çizelge 1. Şeftali-nektarin üreten önemli ülkeler, üretim miktarları ve değişimler.

\begin{tabular}{lrrrr} 
Countries & \multicolumn{2}{c}{$\begin{array}{c}\text { Production quantity (tons) } \\
\text { Üretim miktarı (ton) }\end{array}$} & $\begin{array}{c}\text { Share (\%) } \\
\text { Pay (\%) }\end{array}$ & $\begin{array}{c}\text { Change (\%) } \\
\text { Değişim (\%) }\end{array}$ \\
\cline { 2 - 3 } & \multicolumn{1}{c}{2010} & 2019 & 61.49 & 49.81 \\
China/Çin & $10,563,969$ & $15,825,757$ & 6.01 & 20.14 \\
Spain/İspanya & $1,286,456$ & $1,545,610$ & 4.76 & -22.99 \\
Italy/İtalya & $1,590,660$ & $1,224,940$ & 3.60 & 12.68 \\
Greece/Yunanistan & 822,310 & 926,620 & 3.23 & 53.98 \\
Turkey/Türkiye & 539,403 & 830,577 & 2.87 & -41.04 \\
USA/ABD & $1,254,818$ & 739,900 & 2.30 & 15.37 \\
Iran/İran & 512,608 & 591,412 & 1.39 & 31.02 \\
Egypt/Misir & 273,256 & 358,012 & 1.28 & -7.19 \\
Chile/Şili & 355,814 & 330,232 & 0.82 & -21.05 \\
Argentina/Arjantin & 266,000 & 210,000 & 100.00 & 25.36 \\
World/Dünya & $20,531,684$ & $25,737,841$ & & \\
\hline
\end{tabular}

Table 2. Production areas and changes of major peach-nectarine producing countries.

Çizelge 2. Şeftali-nektarin üreten önemli ülkelerin üretim alanları ve değişimleri.

\begin{tabular}{lrrrr}
\multirow{2}{*}{$\begin{array}{l}\text { Countries } \\
\text { Ülkeler }\end{array}$} & \multicolumn{2}{c}{$\begin{array}{c}\text { Production area (da) } \\
\text { Üretim alanı (da) }\end{array}$} & $\begin{array}{c}\text { Share (\%) } \\
\text { Pay (\%) }\end{array}$ & $\begin{array}{c}\text { Change (\%) } \\
\text { Değişim (\%) }\end{array}$ \\
\cline { 2 - 3 } China/Çin & 2010 & 2019 & 54.93 & 16.15 \\
Spain/İspanya & $7,222,160$ & $8,388,780$ & 5.09 & -6.07 \\
Italy/İtalya & 827,170 & 777,000 & 3.96 & -33.05 \\
Greece/Yunanistan & 902,590 & 604,300 & 2.71 & -5.78 \\
Turkey/Türkiye & 439,510 & 414,100 & 3.03 & 7.41 \\
USA/ABD & 430,990 & 462,940 & 2.38 & -38.82 \\
Iran/İran & 594,610 & 363,800 & 2.11 & -19.37 \\
Egypt/Misır & 398,790 & 321,550 & 1.03 & -52.30 \\
Chile/Şili & 330,170 & 157,480 & 1.02 & -18.91 \\
Argentina/Arjantin & 193,010 & 156,510 & 0.84 & -37.28 \\
World/Dünya & 204,630 & 128,350 & 100.00 & -0.64 \\
\hline
\end{tabular}


The amount of product harvested per unit area is one of the most important factors in modern fruit growing. When Table 3 is examined, it can be said that the peach-nectarine yield increased $26.2 \%$ in the world in 2010-2019, and in parallel with this, important countries in peach-nectarine production also had the necessary share from this increase. With 2,273 and 2,238 $\mathrm{kg}$ yield per unit area, Egypt and Greece had the highest yield, respectively. In contrast with 1,636 and $1,794 \mathrm{~kg}$ yield per unit area Argentina and Turkey had the lowest yield, respectively. Based on the year 2010, the proportional increase in the yield obtained from the unit area was the most in Egypt (174.52\%). Egypt was followed by Turkey $(43.29 \%)$ and Iran $(43.09 \%)$. The USA was the only country that reduced the productivity per unit area (Table 3 ). It is thought that the development of dense planting and training systems and the use of more efficient new rootstocks and varieties caused the increase in Spain $(27.9 \%)$. Turkey had productivity just above the world average $\left(1,686 \mathrm{~kg} \mathrm{da}^{-1}\right)$ with $1,794 \mathrm{~kg} \mathrm{da}$ ${ }^{1}$. The reason for low productivity in Turkey is that it falls behind the other European countries in Research and Development (R\&D) activities. Besides, studies with high density and new training systems have recently been completed, and producers have not yet started such production in Turkey.

\section{Developments in world peach-nectarine trade}

It can be understood from Table 4, that there were changes in terms of both quantity and value when the world peach-nectarine export was evaluated. In 2010-2019, there was an average change of $21 \%$ in peach-nectarine exports. Spain ranks first in exports in terms of both quantity and value. China, Turkey, and Jordan export increased 4.4, 2.5, and 2.3 fold, respectively, in 2010-2019. Another issue that should be taken into account is that Jordan, which was among the leading countries in the export of peach-nectarine in the world exports almost all of its production quantity but does not have a rank in production. It is also noteworthy that Uzbekistan has become one of the important countries in the world peach-nectarine trade since 2017. According to the average export prices in 2019, the USA and China were the countries that sold their products at the best price, while the average prices of these countries were $1.81 \$ \mathrm{~kg}^{-1}$ and $1.63 \$ \mathrm{~kg}^{-1}$, respectively. Among the major exporting countries, Greece had the lowest average peach-nectarine export price, $0.53 \$ \mathrm{~kg}^{-1}$. The average world export price in 2019 was $1.06 \$ \mathrm{~kg}^{-1}$. In the same period, Turkey's export price was 0.85 $\$ \mathrm{~kg}^{-1}$. Spain had the highest share in world trade with $40 \%$ in 2019 . Turkey exported to 21 different countries, taking a share of $5 \%$ of world trade in 2019. However, approximately $95 \%$ of its exports were made to the Russian Federation, Iraq, Belarus, Syria, and Saudi Arabia (Anonymous, 2021b). One of the major reasons why Turkey's export price is low is because Iraq, which imports at low prices, is an important market for Turkey.

Table 3. Yields and changes of major peach-nectarine producing countries.

Çizelge 3. Şeftali-nektarin üreten önemli ülkelerin verim değerleri ve değişimleri.

\begin{tabular}{|c|c|c|c|}
\hline \multirow{2}{*}{$\begin{array}{l}\text { Countries } \\
\text { Ülkeler }\end{array}$} & \multicolumn{2}{|c|}{$\begin{array}{l}\text { Yield }\left(\mathrm{kg} \mathrm{da}^{-1}\right) \\
\text { Verim }\left(\mathrm{kg} \mathrm{da}^{-1}\right) \\
\end{array}$} & \multirow{2}{*}{$\begin{array}{l}\text { Change (\%) } \\
\text { Değişim (\%) }\end{array}$} \\
\hline & 2010 & 2019 & \\
\hline China/Çin & 1,463 & 1,887 & 28.98 \\
\hline Spain/İspanya & 1,555 & 1,989 & 27.91 \\
\hline Italy/İtalya & 1,762 & 2,027 & 15.04 \\
\hline Greece/Yunanistan & 1,871 & 2,238 & 19.62 \\
\hline Turkey/Türkiye & 1,252 & 1,794 & 43.29 \\
\hline USA/ABD & 2,110 & 2,034 & -3.60 \\
\hline Iran/İran & 1,285 & 1,839 & 43.11 \\
\hline Egypt/Misir & 828 & 2,273 & 174.52 \\
\hline Chile/Şili & 1,844 & 2,110 & 14.43 \\
\hline Argentina/Arjantin & 1,300 & 1,636 & 25.85 \\
\hline World/Dünya & 1,336 & 1,685 & 26.12 \\
\hline
\end{tabular}


Table 4. Export quantity, value, price, and changes of major peach-nectarine exporting countries. Çizelge 4. Önemli şeftali-nektarin ihracatçı ülkelerin ihracat miktar, değer, fiyat ve değişimleri.

\begin{tabular}{|c|c|c|c|c|c|c|c|c|}
\hline \multirow[b]{2}{*}{$\begin{array}{l}\text { Countries } \\
\text { Ülkeler }\end{array}$} & \multicolumn{3}{|c|}{2010} & \multicolumn{3}{|c|}{2019} & \multirow[b]{2}{*}{$\begin{array}{c}\text { Share } \\
(\%) \\
\text { Pay }\end{array}$} & \multirow{2}{*}{$\begin{array}{c}\text { Change in } \\
\text { quantity } \\
(\%) \\
\text { Miktardaki } \\
\text { değişim }\end{array}$} \\
\hline & $\begin{array}{c}\text { Quantity } \\
\text { (tons) } \\
\text { Miktar }\end{array}$ & $\begin{array}{c}\text { Value } \\
(1000 \$) \\
\text { Değer }\end{array}$ & $\begin{array}{c}\text { Price } \\
\left(\$ \mathrm{~kg}^{-1}\right) \\
\text { Fiyat }\end{array}$ & $\begin{array}{c}\text { Quantity } \\
\text { (tons) } \\
\text { Miktar }\end{array}$ & $\begin{array}{c}\text { Value } \\
(1000 \$) \\
\text { Değer }\end{array}$ & $\begin{array}{l}\text { Price } \\
\left(\$ \mathrm{~kg}^{-1}\right) \\
\text { Fiyat }\end{array}$ & & \\
\hline Spain/İspanya & 585,127 & 833,884 & 1.43 & 828,812 & 859,608 & 1.04 & 40.07 & 41.65 \\
\hline Greece/Yunanistan & 117,471 & 108,886 & 0.93 & 163,557 & 87,313 & 0.53 & 7.91 & 39.23 \\
\hline Italy/İtalya & 359,780 & 395,795 & 1.10 & 157,889 & 149,966 & 0.95 & 7.63 & -56.12 \\
\hline China/Çin & 27,802 & 12,977 & 0.47 & 121,153 & 197,466 & 1.63 & 5.86 & 335.77 \\
\hline Chile/Şili & 91,401 & 129,923 & 1.42 & 108,800 & 110,885 & 1.02 & 5.26 & 19.04 \\
\hline Turkey/Türkiye & 41,326 & 28,815 & 0.70 & 105,331 & 89,784 & 0.85 & 5.09 & 154.88 \\
\hline USA/ABD & 115,081 & 170,480 & 1.48 & 72,703 & 131,618 & 1.81 & 3.52 & -36.82 \\
\hline Jordan/Ürdün & 30,629 & 47,170 & 1.54 & 70,183 & 55,415 & 0.79 & 3.39 & 129.14 \\
\hline Uzbekistan/Özbekistan & -- & -- & -- & 56,425 & 46,036 & 0.82 & 2.73 & -- \\
\hline Netherland/Hollanda & 20,030 & 36,940 & 1.84 & 31,877 & 44,361 & 1.39 & 1.54 & 59.15 \\
\hline World/Dünya & $1,709,047$ & $2,179,646$ & 1.28 & $2,068,364$ & $2,184,524$ & 1.06 & 100.00 & 21.02 \\
\hline
\end{tabular}

The import quantity, value, price, and changes of the countries that import the most peach-nectarine are given in Table 5. According to the data of 2019, Germany was the country that imported the most peach-nectarine with a share of $14.5 \%$. Germany is followed by the Russian Federation $(9.03 \%)$, France $(7.49 \%)$, Poland $(5.54 \%)$, Italy $(5.27 \%)$, United Kingdom (UK) (4.60\%), Netherlands (3.05\%), Iraq $(2.98 \%)$, Portugal $(2.78 \%)$, and Kazakhstan $(2.77 \%)$, respectively. The Netherlands and Italy are both important importing and exporting countries. Turkey imports scarely any peach-nectarine. In 2019, 384 tons peach-nectarine were imported. Considering the import prices, it is possible to see from Table 5 that the world average was $1.16 \$ \mathrm{~kg}^{-1}$, the UK realized the highest-priced imports with $1.50 \$ \mathrm{~kg}^{-1}$, and Iraq realized the lowest-priced imports with $0.66 \$ \mathrm{~kg}^{-1}$.

\section{Developments and forecasts in Turkey peach- nectarine production and trade}

According to 2020 data, the most peach-nectarine was produced in Çanakkale province with 178.472 tons (Anonymous, 2021c). Çanakkale was followed by Mersin, Bursa, Denizli, and İzmir provinces, and about $71 \%$ of Turkey's production took place in these five provinces. Figure 1 shows the production shares of major peach-nectarineproducing provinces.

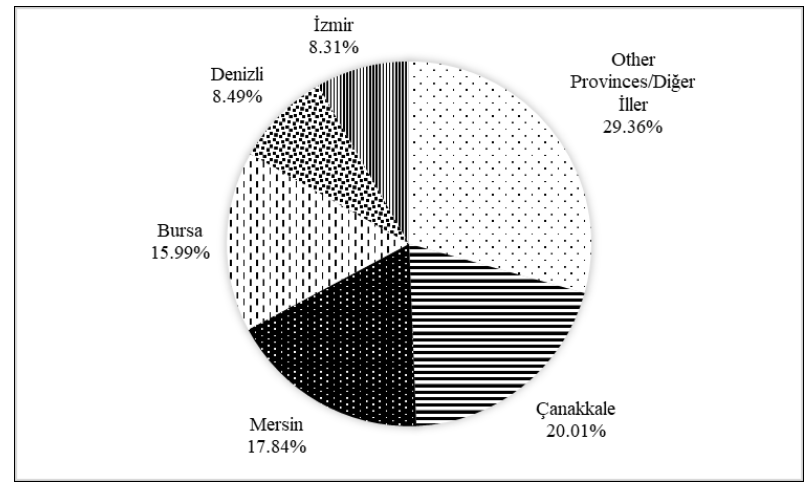

Figure 1. Production shares of major peach-nectarineproducing provinces.

Şekil 1. Önemli şeftali-nektarin üreten illerin üretimdeki payları.

Before forecasting with 50-year data, the stationarity of the time series was checked, and it was determined by the ADF test that the series was not stationary. It was determined that the time series's first difference became stationary according to the trend and intercept ADF test. Autocorrelation $(\mathrm{ACF})$ and partial autocorrelation (PACF) plots of the time series were examined (Figure 2), and it was concluded that there is no seasonal fluctuation and the model should be the autoregressive integrated moving average (ARIMA). 
Table 5. Import quantity, value, price, and changes of major peach-nectarine importing countries.

Çizelge 5. Önemli şeftali-nektarin ithalatçı ülkelerin ithalat miktar, değer, fiyat ve değişimleri.

\begin{tabular}{|c|c|c|c|c|c|c|c|c|}
\hline \multirow[b]{2}{*}{$\begin{array}{l}\text { Countries } \\
\text { Ülkeler }\end{array}$} & \multicolumn{3}{|c|}{2010} & \multicolumn{4}{|c|}{2019} & \multirow[b]{2}{*}{$\begin{array}{c}\text { Change in } \\
\text { quantity } \\
(\%) \\
\text { Miktardaki } \\
\text { değişim }\end{array}$} \\
\hline & $\begin{array}{l}\text { Quantity } \\
\text { (tons) } \\
\text { Miktar }\end{array}$ & $\begin{array}{c}\text { Value } \\
(1000 \$) \\
\text { Değer }\end{array}$ & $\begin{array}{l}\text { Price } \\
\left(\$ \mathrm{~kg}^{-1}\right) \\
\text { Fiyat }\end{array}$ & $\begin{array}{c}\text { Quantity } \\
\text { (tons) } \\
\text { Miktar }\end{array}$ & $\begin{array}{c}\text { Value } \\
(1000 \$) \\
\text { Değer }\end{array}$ & $\begin{array}{c}\text { Price } \\
\left(\$ \mathrm{~kg}^{-1}\right) \\
\text { Fiyat }\end{array}$ & $\begin{array}{c}\text { Share } \\
(\%) \\
\text { Pay }\end{array}$ & \\
\hline $\begin{array}{l}\text { Germany } \\
\text { Almanya }\end{array}$ & 291,173 & 406,355 & 1.40 & 301,509 & 355,319 & 1.18 & 14.50 & 3.55 \\
\hline $\begin{array}{l}\text { Russian Federation } \\
\text { Rusya Federasyonu }\end{array}$ & 225,653 & 241,815 & 1.07 & 187,858 & 214,016 & 1.14 & 9.03 & -16.75 \\
\hline $\begin{array}{l}\text { France } \\
\text { Fransa }\end{array}$ & 115,726 & 186,509 & 1.61 & 155,739 & 180,301 & 1.16 & 7.49 & 34.58 \\
\hline $\begin{array}{l}\text { Poland } \\
\text { Polonya }\end{array}$ & 91,915 & 91,141 & 0.99 & 115,159 & 103,844 & 0.90 & 5.54 & 25.29 \\
\hline $\begin{array}{l}\text { Italy } \\
\text { İtalya }\end{array}$ & 59,456 & 89,081 & 1.50 & 109,567 & 112,220 & 1.02 & 5.27 & 84.28 \\
\hline $\begin{array}{l}\text { United Kingdom } \\
\text { Birleşik Krallık }\end{array}$ & 63,507 & 105,865 & 1.67 & 95,603 & 143,809 & 1.50 & 4.60 & 50.54 \\
\hline $\begin{array}{l}\text { Netherlands } \\
\text { Hollanda }\end{array}$ & 74,467 & 77,119 & 1.04 & 63,460 & 77,309 & 1.22 & 3.05 & -14.78 \\
\hline $\begin{array}{l}\text { Iraq } \\
\text { Irak }\end{array}$ & -- & -- & -- & 62,062 & 40,875 & 0.66 & 2.98 & -- \\
\hline $\begin{array}{l}\text { Portugal } \\
\text { Portekiz }\end{array}$ & 45,652 & 45,078 & 0.99 & 57,734 & 40,434 & 0.70 & 2.78 & 26.47 \\
\hline $\begin{array}{l}\text { Kazakhstan } \\
\text { Kazakistan }\end{array}$ & 9,857 & 5,101 & 0.52 & 57,559 & 45,328 & 0.79 & 2.77 & 483.94 \\
\hline $\begin{array}{l}\text { World } \\
\text { Dünya }\end{array}$ & $1,707,881$ & $2,209,684$ & 1.29 & $2,080,017$ & $2,422,988$ & 1.16 & 100.00 & 21.79 \\
\hline
\end{tabular}

The results showed that the series could be predicted using the "non-seasonal Box-Jenkins method". The appropriate ARIMA model selection was determined using the automatic ARIMA selection feature in the EViews10 statistical package program. As a result, it was concluded that the most suitable ARIMA model is ARIMA $(1,1,0)$. Production forecasts for the next three years with the Box-Jenkins method are given in Table 6. Provided that the structural risks of agricultural production are not forgotten, it was forecasted that Turkey's peach-nectarine production would increase to $893,575,914,301$, and 928,877 tons in 2021, 2022, and 2023, respectively. In addition, the lowest and highest production values were given in the $95 \%$ confidence interval.

As in the forecasting of the production quantity, 50 -year data were used to forecast the export quantity. First, the stationarity of the time series was checked before the forecast, and it was determined by the ADF test that the series was not stationary. It was determined that the time series's first difference became stationary according to the trend and intercept ADF test. ACF and PACF plots of the time series were examined (Figure 3), and it was concluded that there is no seasonal fluctuation and the model should be the autoregressive integrated moving average (ARIMA).

Table 6. Turkey peach-nectarine production forecast (tons).

Çizelge 6. Türkiye şeftali-nektarin üretim tahmini (ton).

\begin{tabular}{lccc}
$\begin{array}{l}\text { Year } \\
\text { Y11 }\end{array}$ & $\begin{array}{c}\text { Forecast } \\
\text { Tahmin }\end{array}$ & $\begin{array}{c}\text { Lowest } \\
\text { En düşük }\end{array}$ & $\begin{array}{c}\text { Highest } \\
\text { En yüksek }\end{array}$ \\
\hline 2021 & 893,575 & 818,080 & 969,070 \\
2022 & 914,301 & 823,016 & $1,005,585$ \\
2023 & 928,877 & 820,153 & $1,037,602$ \\
\hline
\end{tabular}



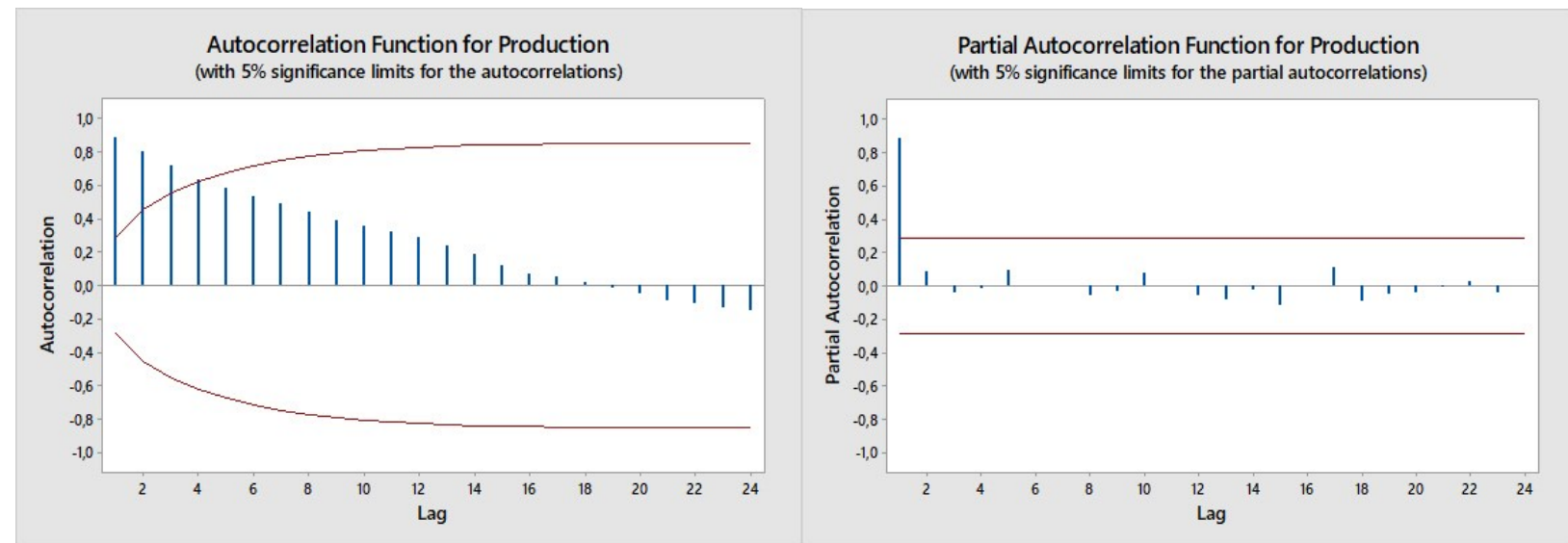

Figure 2. The autocorrelation (ACF) and partial autocorrelation (PACF) plots of peach-nectarine production. Şekil 2. Şeftali-nektarin üretimine ait otokorelasyon (ACF) ve kısmi otokorelasyon (PACF) grafikleri.
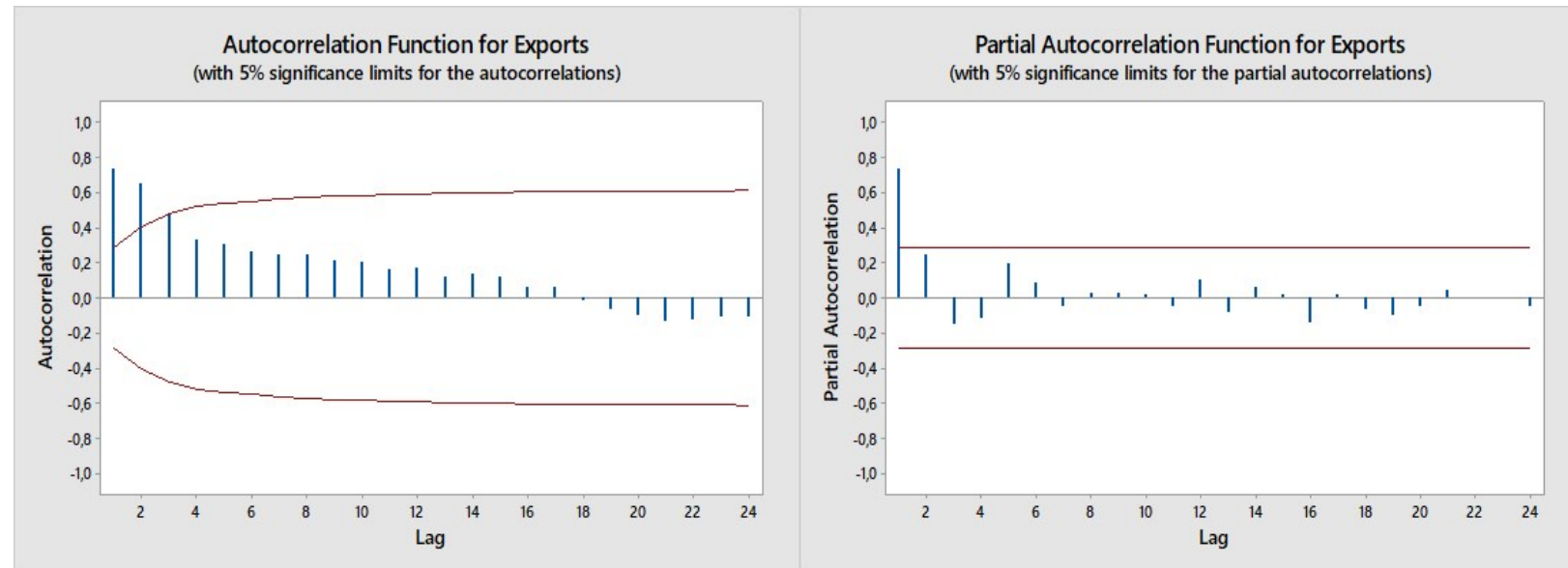

Figure 3. The autocorrelation (ACF) and partial autocorrelation (PACF) plots of peach-nectarine exports. Şekil 3. Şeftali-nektarin ihracatına ait otokorelasyon (ACF) ve kısmi otokorelasyon (PACF) grafikleri.

The results showed that the series could be predicted using the "non-seasonal Box-Jenkins method". The appropriate ARIMA model selection was determined using the automatic ARIMA selection feature in the EViews10 statistical package program. As a result, it was concluded that the most suitable ARIMA model is ARIMA $(0,1,2)$. Export forecasts for the next three years with the Box-Jenkins method are given in Table 7. According to the forecasts, in the $95 \%$ confidence interval, Turkey's peach-nectarine exports will be between 119,632 tons and 195,053 tons in 2023. It was forecasted that Turkey's peach-nectarine exports would be 144,158 tons in 2021, would increase by approximately 10,000 tons in 2022 , and reach 157,343 tons in 2023.

\section{Turkey's competitiveness analysis}

The top ten countries in the world peach-nectarine export ranking were considered Turkey's rivals, and the indices developed by Balassa and Vollrath were calculated based on the export values for 2010-2019.

Table 7. Turkey peach-nectarine exports forecast (tons). Çizelge 7. Türkiye şeftali-nektarin ihracat tahmini (ton).

\begin{tabular}{lccc}
\hline $\begin{array}{l}\text { Year } \\
\text { Y1l }\end{array}$ & $\begin{array}{c}\text { Forecast } \\
\text { Tahmin }\end{array}$ & $\begin{array}{c}\text { Lowest } \\
\text { En düşük }\end{array}$ & $\begin{array}{c}\text { Highest } \\
\text { En yüksek }\end{array}$ \\
\hline 2021 & 144,158 & 121,910 & 166,406 \\
2022 & 154,376 & 129,396 & 179,356 \\
2023 & 157,343 & 119,632 & 195,053 \\
\hline
\end{tabular}


The RCA values of Balassa were given in Table 8 . Turkey's RCA values remained close to each other until 2016, and Turkey had a weak comparative advantage. Turkey had a high degree of comparative advantage, especially after 2017. Despite the fall RCA index value in recent years, Jordan, Spain, Greece, Chile, and Uzbekistan, which have important ranks in the peach-nectarine exports since 2017, compared with Turkey, have been much higher comparative advantages. Italy has been gradually losing its comparative advantage in recent years. China, the USA, and the Netherlands had a comparative disadvantage. Given in Table 8, according to the average of 2010-2019, Turkey had a medium comparative advantage. Turkey's RCA values compared to Jordan, Uzbekistan, Greece, Spain, Chile, and Italy, indicated that it was relatively more advantageous. When the coefficient of variation $(\mathrm{CV})$ is taken into account, Spain and the Netherlands stand out as the countries with the lowest CV over the years, the least change over the years. On the other hand, the CV of index values of China and Turkey were calculated to be higher than other countries. This means that RCA values differ from year to year in China and Turkey.
RXA index values of Vollrath are given in Table 9. RXA values are close to RCA values. An RXA index value greater than 1 for Turkey's export performance indicates that it is higher than the world's export performance. Similarly, RXA index values calculated for Jordan, Spain, Uzbekistan, Greece, Chile, and Italy were greater than 1 . China, Netherlands, and USA RXA values were calculated to be less than 1 . In other words, the export performance of these countries was not better than the world export performance. The CV of the RXA index values showed a parallel feature to the $\mathrm{CV}$ of RCA index values.

In Table 10, RMP values are given. According to the RMP index values, all countries except Italy and the Netherlands had a relative advantage in the peach-nectarine sector. In particular, Uzbekistan and Turkey had lower RMP values, showing that they had a more comparative advantage in the peach-nectarine sector. The lowest CV was taken from Uzbekistan and it was followed by the Netherlands, while it was the highest in China and followed by Turkey.

Table 8. Balassa's revealed comparative advantage index (RCA). Çizelge 8. Balassa'nın açıklanmış karşılaştırmalı üstünlük endeksi (RCA).

\begin{tabular}{lcccccccccc}
\hline Year & $\begin{array}{c}\text { Turkey } \\
\text { Y1l }\end{array}$ & $\begin{array}{c}\text { Spain } \\
\text { Türiye }\end{array}$ & $\begin{array}{c}\text { İspanya } \\
\text { Çina }\end{array}$ & $\begin{array}{c}\text { Italy } \\
\text { İtalya }\end{array}$ & $\begin{array}{c}\text { Chile } \\
\text { Şili }\end{array}$ & $\begin{array}{c}\text { USA } \\
\text { ABD }\end{array}$ & $\begin{array}{c}\text { Greece } \\
\text { Yunanistan }\end{array}$ & $\begin{array}{c}\text { Jordan } \\
\text { Ürdün }\end{array}$ & $\begin{array}{c}\text { Netherland } \\
\text { Hollanda }\end{array}$ & $\begin{array}{c}\text { Uzbekistan } \\
\text { Özbekistan }\end{array}$ \\
\hline 2010 & 1.75 & 23.45 & 0.06 & 6.13 & 12.65 & 0.92 & 27.34 & 46.51 & 0.52 & -- \\
2011 & 1.39 & 22.97 & 0.13 & 5.34 & 13.77 & 0.93 & 22.99 & 80.47 & 0.63 & -- \\
2012 & 1.46 & 22.89 & 0.18 & 5.90 & 13.18 & 0.95 & 29.94 & 96.55 & 0.50 & -- \\
2013 & 1.39 & 24.58 & 0.15 & 5.31 & 12.12 & 0.87 & 23.08 & 91.73 & 0.57 & -- \\
2014 & 1.82 & 24.68 & 0.29 & 3.71 & 11.32 & 0.97 & 26.11 & 61.55 & 0.50 & -- \\
2015 & 2.00 & 24.02 & 0.43 & 3.73 & 11.72 & 0.75 & 21.04 & 110.71 & 0.54 & -- \\
2016 & 1.35 & 23.17 & 0.39 & 3.66 & 13.22 & 0.76 & 25.16 & 85.79 & 0.61 & -- \\
2017 & 3.51 & 22.80 & 0.49 & 3.00 & 10.92 & 0.65 & 21.59 & 85.27 & 0.59 & 18.83 \\
2018 & 4.48 & 23.39 & 0.31 & 3.05 & 12.62 & 0.70 & 21.44 & 59.02 & 0.61 & 33.26 \\
2019 & 4.49 & 21.83 & 0.68 & 2.41 & 13.73 & 0.69 & 19.74 & 57.09 & 0.66 & 27.48 \\
Mean & 2.36 & 23.38 & 0.31 & 4.22 & 12.53 & 0.82 & 23.84 & 77.47 & 0.57 & 26.53 \\
CV (\%) & 54.35 & 3.70 & 61.37 & 31.43 & 7.89 & 14.83 & 13.49 & 26.45 & 9.81 & 27.38 \\
\hline
\end{tabular}

CV: Coefficient of Variation. /Varyasyon Katsayıs1. 
Table 9. Vollrath's relative export advantage index (RXA).

Çizelge 9. Vollrath'ın göreli ihracat avantajı endeksi (RXA).

\begin{tabular}{|c|c|c|c|c|c|c|c|c|c|c|}
\hline $\begin{array}{l}\text { Year } \\
\text { Y11 }\end{array}$ & $\begin{array}{l}\text { Turkey } \\
\text { Türkiye }\end{array}$ & $\begin{array}{c}\text { Spain } \\
\text { İspanya }\end{array}$ & $\begin{array}{l}\text { China } \\
\text { Çin }\end{array}$ & $\begin{array}{l}\text { Italy } \\
\text { İtalya }\end{array}$ & $\begin{array}{l}\text { Chile } \\
\text { Şili }\end{array}$ & $\begin{array}{l}\text { USA } \\
\text { ABD }\end{array}$ & $\begin{array}{c}\text { Greece } \\
\text { Yunanistan }\end{array}$ & $\begin{array}{l}\text { Jordan } \\
\text { Ürdün }\end{array}$ & $\begin{array}{l}\text { Netherland } \\
\text { Hollanda }\end{array}$ & $\begin{array}{l}\text { Uzbekistan } \\
\text { Özbekistan }\end{array}$ \\
\hline 2010 & 1.76 & 37.36 & 0.05 & 7.27 & 13.39 & 0.92 & 28.72 & 47.52 & 0.51 & -- \\
\hline 2011 & 1.40 & 36.35 & 0.11 & 6.13 & 14.61 & 0.93 & 23.96 & 83.39 & 0.62 & -- \\
\hline 2012 & 1.47 & 34.97 & 0.16 & 6.84 & 13.90 & 0.94 & 31.70 & 100.67 & 0.50 & -- \\
\hline 2013 & 1.39 & 40.63 & 0.13 & 6.04 & 12.69 & 0.86 & 24.10 & 95.36 & 0.56 & -- \\
\hline 2014 & 1.84 & 41.64 & 0.26 & 4.03 & 11.81 & 0.97 & 27.42 & 63.26 & 0.49 & -- \\
\hline 2015 & 2.01 & 39.72 & 0.39 & 4.05 & 12.21 & 0.74 & 21.79 & 116.83 & 0.53 & -- \\
\hline 2016 & 1.36 & 38.76 & 0.36 & 3.98 & 13.84 & 0.75 & 26.27 & 89.37 & 0.60 & -- \\
\hline 2017 & 3.59 & 37.61 & 0.46 & 3.19 & 11.35 & 0.63 & 22.44 & 88.44 & 0.59 & 19.02 \\
\hline 2018 & 4.62 & 39.55 & 0.28 & 3.25 & 13.22 & 0.68 & 22.38 & 60.43 & 0.60 & 33.88 \\
\hline 2019 & 4.64 & 35.35 & 0.64 & 2.52 & 14.41 & 0.66 & 20.52 & 58.55 & 0.65 & 28.05 \\
\hline Mean & 2.41 & 38.19 & 0.29 & 4.73 & 13.14 & 0.81 & 24.93 & 80.38 & 0.57 & 26.99 \\
\hline CV (\%) & 55.72 & 5.87 & 64.23 & 35.62 & 8.39 & 16.07 & 14.14 & 27.40 & 9.77 & 27.75 \\
\hline
\end{tabular}

CV: Coefficient of Variation. /Varyasyon Katsayıs1.

Table 10. Vollrath's relative import penetration index (RMP).

Çizelge 10. Vollrath'ın göreli ithalat avantajı endeksi (RMP).

\begin{tabular}{|c|c|c|c|c|c|c|c|c|c|c|}
\hline $\begin{array}{l}\text { Year } \\
\text { Y11 }\end{array}$ & $\begin{array}{l}\text { Turkey } \\
\text { Türkiye }\end{array}$ & $\begin{array}{c}\text { Spain } \\
\text { İspanya }\end{array}$ & $\begin{array}{c}\text { China } \\
\text { Çin }\end{array}$ & $\begin{array}{c}\text { Italy } \\
\text { Ittalya }\end{array}$ & $\begin{array}{c}\text { Chile } \\
\text { Şili }\end{array}$ & $\begin{array}{l}\text { USA } \\
\text { ABD }\end{array}$ & $\begin{array}{c}\text { Greece } \\
\text { Yunanistan }\end{array}$ & $\begin{array}{l}\text { Jordan } \\
\text { Ürdün }\end{array}$ & $\begin{array}{c}\text { Netherland } \\
\text { Hollanda }\end{array}$ & $\begin{array}{l}\text { Uzbekistan } \\
\text { Özbekistan }\end{array}$ \\
\hline 2010 & 0.0035 & 0.39 & 0.000 & 1.28 & 0.06 & 0.27 & 0.42 & 0.09 & 1.22 & -- \\
\hline 2011 & 0.0034 & 0.35 & 0.000 & 1.53 & 0.04 & 0.23 & 0.62 & 0.18 & 1.52 & -- \\
\hline 2012 & 0.0022 & 0.22 & 0.000 & 1.26 & 0.01 & 0.20 & 0.18 & 0.26 & 1.50 & -- \\
\hline 2013 & 0.0010 & 0.16 & 0.000 & 1.55 & 0.02 & 0.18 & 0.18 & 0.29 & 1.45 & -- \\
\hline 2014 & 0.0009 & 0.21 & 0.000 & 1.84 & 0.06 & 0.17 & 0.31 & 0.42 & 1.28 & -- \\
\hline 2015 & 0.0032 & 0.31 & 0.000 & 1.99 & 0.04 & 0.22 & 0.34 & 0.58 & 1.29 & -- \\
\hline 2016 & 0.0019 & 0.12 & 0.005 & 1.78 & 0.10 & 0.31 & 0.24 & 1.08 & 1.41 & -- \\
\hline 2017 & 0.0041 & 0.12 & 0.089 & 1.72 & 0.09 & 0.24 & 0.26 & 0.76 & 1.24 & 0.008 \\
\hline 2018 & 0.0081 & 0.17 & 0.195 & 2.13 & 0.10 & 0.26 & 0.24 & 0.33 & 1.29 & 0.009 \\
\hline 2019 & 0.0121 & 0.13 & 0.263 & 1.91 & 0.08 & 0.24 & 0.29 & 0.44 & 1.19 & 0.008 \\
\hline Mean & 0.0040 & 0.22 & 0.055 & 1.70 & 0.06 & 0.23 & 0.31 & 0.44 & 1.34 & 0.008 \\
\hline CV (\%) & 86.51 & 45.40 & 175.71 & 17.11 & 53.86 & 18.26 & 42.69 & 66.84 & 8.99 & 6.93 \\
\hline
\end{tabular}

CV: Coefficient of Variation. /Varyasyon Katsayısı.

In Table 11, RTA values are given. Since a positive RTA value is an indicator of competitive advantage, it was possible to say that all countries, except the Netherland, had a competitive advantage. However, considering the average, it was concluded that China and the USA's competitiveness is lower than other countries. According to the RTA index values, Spain showed the lowest CV, and Italy and Turkey showed the highest $\mathrm{CV}$.

$\mathrm{RC}$ values are given in Table 12. When the table is examined, it is seen that there were some differences according to the RTA index results. The Netherlands did not have a comparative advantage in the $\mathrm{RC}$ index as in all indices. However, a remarkable issue was that although Italy had a positive value on average, it remained lower than other countries. After Uzbekistan, Turkey stood out as the country with the highest comparative advantage. The $\mathrm{CV}$ of the $\mathrm{RC}$ index showed that the RC index of Uzbekistan, Turkey, and Spain were close to each other over the years. 
Table 11. Vollrath's relative trade advantage index (RTA).

Çizelge 11. Vollrath'ın göreli ticaret avantaji endeksi (RTA).

\begin{tabular}{lcccccccccc}
\hline $\begin{array}{l}\text { Year } \\
\text { Y1l }\end{array}$ & $\begin{array}{c}\text { Turkey } \\
\text { Türkiye }\end{array}$ & $\begin{array}{c}\text { İspain } \\
\text { İspana }\end{array}$ & $\begin{array}{c}\text { China } \\
\text { Çin }\end{array}$ & $\begin{array}{c}\text { Italy } \\
\text { İtalya }\end{array}$ & $\begin{array}{c}\text { Chile } \\
\text { Şili }\end{array}$ & $\begin{array}{c}\text { USA } \\
\text { ABD }\end{array}$ & $\begin{array}{c}\text { Greece } \\
\text { Yunanistan }\end{array}$ & $\begin{array}{c}\text { Jordan } \\
\text { Ürdün }\end{array}$ & $\begin{array}{c}\text { Netherland } \\
\text { Hollanda }\end{array}$ & $\begin{array}{c}\text { Uzbekistan } \\
\text { Özbekistan }\end{array}$ \\
\hline 2010 & 1.76 & 36.97 & 0.05 & 5.99 & 13.33 & 0.64 & 28.30 & 47.43 & -0.71 & -- \\
2011 & 1.39 & 36.00 & 0.11 & 4.60 & 14.57 & 0.70 & 23.34 & 83.21 & -0.90 & -- \\
2012 & 1.47 & 34.74 & 0.16 & 5.59 & 13.89 & 0.75 & 31.52 & 100.40 & -1.01 & -- \\
2013 & 1.39 & 40.47 & 0.13 & 4.49 & 12.68 & 0.68 & 23.92 & 95.07 & -0.89 & -- \\
2014 & 1.83 & 41.43 & 0.26 & 2.19 & 11.75 & 0.80 & 27.10 & 62.84 & -0.79 & -- \\
2015 & 2.01 & 39.41 & 0.39 & 2.06 & 12.18 & 0.52 & 21.46 & 116.24 & -0.75 & -- \\
2016 & 1.35 & 38.64 & 0.35 & 2.19 & 13.74 & 0.44 & 26.04 & 88.29 & -0.81 & -- \\
2017 & 3.58 & 37.49 & 0.37 & 1.46 & 11.26 & 0.38 & 22.18 & 87.69 & -0.65 & 19.02 \\
2018 & 4.61 & 39.39 & 0.09 & 1.11 & 13.12 & 0.41 & 22.14 & 60.10 & -0.68 & 33.87 \\
2019 & 4.63 & 35.22 & 0.38 & 0.61 & 14.33 & 0.42 & 20.23 & 58.11 & -0.54 & 28.05 \\
Mean & 2.40 & 37.97 & 0.23 & 3.03 & 13.08 & 0.57 & 24.62 & 79.94 & -0.77 & 26.98 \\
CV (\%) & 55.76 & 5.94 & 59.00 & 64.42 & 8.44 & 27.40 & 14.38 & 27.42 & -17.79 & 27.73 \\
\hline
\end{tabular}

CV: Coefficient of Variation. /Varyasyon Katsayisı.

Table 12. Vollrath's revealed competitiveness (RC).

Çizelge 12. Vollrath'ın açıklanmış rekabet endeksi (RC).

\begin{tabular}{|c|c|c|c|c|c|c|c|c|c|c|}
\hline $\begin{array}{l}\text { Year } \\
\text { Y1l } \\
\end{array}$ & $\begin{array}{c}\text { Turkey } \\
\text { Türkiye }\end{array}$ & $\begin{array}{c}\text { Spain } \\
\text { İspanya }\end{array}$ & $\begin{array}{c}\text { China } \\
\text { Çin }\end{array}$ & $\begin{array}{c}\text { Italy } \\
\text { İtalya }\end{array}$ & $\begin{array}{c}\text { Chile } \\
\text { Şili }\end{array}$ & $\begin{array}{l}\text { USA } \\
\text { ABD }\end{array}$ & $\begin{array}{c}\text { Greece } \\
\text { Yunanistan }\end{array}$ & $\begin{array}{l}\text { Jordan } \\
\text { Ürdün }\end{array}$ & $\begin{array}{c}\text { Netherland } \\
\text { Hollanda }\end{array}$ & $\begin{array}{l}\text { Uzbekistan } \\
\text { Özbekistan }\end{array}$ \\
\hline 2010 & 6.23 & 4.56 & 8.65 & 1.74 & 5.41 & 1.21 & 4.23 & 6.27 & -0.87 & -- \\
\hline 2011 & 6.02 & 4.64 & 10.21 & 1.39 & 5.96 & 1.41 & 3.66 & 6.14 & -0.90 & -- \\
\hline 2012 & 6.51 & 5.05 & -- & 1.69 & 6.90 & 1.57 & 5.18 & 5.95 & -1.11 & -- \\
\hline 2013 & 7.28 & 5.55 & -- & 1.36 & 6.66 & 1.56 & 4.90 & 5.79 & -0.95 & -- \\
\hline 2014 & 7.65 & 5.30 & 11.21 & 0.78 & 5.30 & 1.74 & 4.47 & 5.02 & -0.96 & -- \\
\hline 2015 & 6.44 & 4.84 & -- & 0.71 & 5.80 & 1.21 & 4.17 & 5.30 & -0.88 & -- \\
\hline 2016 & 6.57 & 5.77 & 4.18 & 0.80 & 4.97 & 0.90 & 4.71 & 4.42 & -0.86 & -- \\
\hline 2017 & 6.77 & 5.72 & 1.64 & 0.61 & 4.85 & 0.94 & 4.45 & 4.76 & -0.75 & 7.80 \\
\hline 2018 & 6.35 & 5.48 & 0.37 & 0.42 & 4.88 & 0.95 & 4.52 & 5.21 & -0.76 & 8.18 \\
\hline 2019 & 5.95 & 5.61 & 0.90 & 0.28 & 5.16 & 1.02 & 4.27 & 4.89 & -0.60 & 8.22 \\
\hline Mean & 6.58 & 5.25 & 5.31 & 0.98 & 5.59 & 1.25 & 4.46 & 5.38 & -0.86 & 8.07 \\
\hline $\mathrm{CV}(\%)$ & 8.16 & 8.57 & 87.21 & 53.66 & 13.03 & 24.32 & 9.46 & 11.75 & -15.98 & 2.90 \\
\hline
\end{tabular}

CV: Coefficient of Variation. /Varyasyon Katsayıs1.

For Turkey, the RCA, RXA, and RTA indices above 1 indicate a comparative advantage in exports. When these index values for 2010-2019 were examined, it was seen that they were on an increasing trend. Although the high coefficient of variation of RCA index values indicated an unstable export, the height of the RC index values and its low coefficient of variation showed that the peach-nectarine sector in Turkey had an important position that had a comparative advantage. When the values of all indices are evaluated as a whole, it is estimated that the Netherlands is not an important producer therefore it cannot have a comparative advantage. China and the USA will not be able to maintain their already low relative advantages due to population pressure, and the relative advantage of Italy, which tends to decrease, will decrease further due to the increase in the quantity of production in other countries. It is thought that, especially if Uzbekistan's rapid entry into the peach-nectarine trade continues with the same trend in recent years, it will not be very difficult for it to rise to the top. Spain, Jordan, Greece, Chile, and Turkey are expected to continue their comparative advantage in the peach-nectarine trade in the coming years. 


\section{CONCLUSION}

This study evaluated developments in Turkey and the world's peach-nectarine production and trade during 2010-2019 and forecasted future production and export quantity of Turkey for three years, and competitiveness analysis was conducted on the major exporting countries.

As in many products, China alone met the vast majority of world production (about 61\%) in peach-nectarine. Turkey provided $3.23 \%$ of world production and ranked $5^{\text {th }}$ in terms of production. Considering the increase in production rate, Turkey increased above the world average in the years 2010-2019.

In parallel with the increase in peach and nectarine production quantity in the world, there was a significant increase in trade. Considering the period of 2010-2019, there was an increase of $21 \%$ in world trade. In the same period, the country that increased the export quantity the most, proportionally, was China, followed by Turkey, Jordan, and Uzbekistan. Neraly all of Turkey's export was done to the Russian Federation, Iraq, Belarus, Syria, and Saudi Arabia. The countries that import the most peach-nectarine were Germany, Russian Federation, France, Poland, and Italy.

The production quantities and export forecasts for Turkey were made using the Box-Jenkins method for 2021, 2022, and 2023. The analysis results showed that Turkey's peach-nectarine production in 2023 would reach 928,877 tons, and export would reach 157,343 tons. However, it should be taken into account that agricultural production faces many risks, especially for species such as peach and nectarine that are susceptible to late spring frosts, diseases, and pests.

There is great competition in the world's peach and nectarine sector. In this study, Turkey's competitiveness in peaches and nectarines export was analyzed in comparison with competitor countries. All the calculated indices showed that Turkey had a comparative advantage. Especially Spain, Uzbekistan, and Greece are considered as our most important competitors in foreign trade in terms of the production season's coincidence. Calculated indices are sensitive to barriers (tariff and non-tariff barriers) encountered in foreign trade. To prevent this sensitivity and maintain Turkey's comparative advantage, it is essential to continue searching for new markets in peachnectarine foreign trade.

Turkey is a country with significant export opportunities for peach-nectarine production due to its ecological structure and self-sufficiency. However, despite having sufficient potential, to date, Turkey has not achieved its desired share from the global peach-nectarine market. In order to improve Turkey's current position in world production and trade of peach-nectarine, and especially to have a say in the world peachnectarine trade, developments in production should be closely followed. In developed countries, traditional production methods were replaced by consumer-oriented modern methods to respond to international market demands. Particularly, highdensity planting systems and farming methods with new rootstocks gained importance. Spain, which ranks second in world production, and Italy, ranked third, produce using the above-mentioned modern farming methods. New plantations have been established with the clonal Rootpac series rootstocks (Rootpac-R, Rootpac-90, Rootpac-70, Rootpac-40, Rootpac-20), which are suitable highdensity planting developed especially in Spain. This development resulted in a decrease in production areas and an increase in productivity. Although Turkey has not yet performed this conversion, it has started the necessary $R \& D$ which is considered a promising development. Turkey has an important place in peach-nectarine production but establishing orchards with clonal rootstocks that enable high-density planting should be extended. It is important to establish the new orchards considering the new technological developments and sustainability. Production fluctuations caused by late spring frosts can be prevented, especially by choosing suitable varieties (early varieties for coastal regions, late varieties for interior regions) for the region's climate conditions and market. Increased production of early varieties will increase Turkey's exports. For this purpose, early varieties' sapling production should be increased, breeding studies should be started, and new marketing strategies should be developed. 


\section{REFERENCES}

Anonymous, 2021a. Food and Agriculture Organization of the United Nations. Available at: http://www.fao.org/faostat/en/\#data. Rome, ITALY.

Anonymous, 2021b. International Trade Center, Trade statistics for international business development. Available at: https://www.trademap.org/.

Anonymous, 2021c. Turkish Statistical Institute. Available at:https://www.tuik.gov.tr/. Ankara, TURKEY.

Balassa, B. 1965. Trade liberalization and revealed comparative advantage. The Manchester School of Economic and Social Studies 33 (2):99-123.

Balc1, D., and F. H. Giray 2020. Competitive analysis of Isparta fruit sector through diamond model. Turkish Journal of Agriculture - Food Science and Technology $8(3)$ : 784-792 https://doi.org/10.24925/turjaf.v8i3.784-792.3358

Berk, A., T. Bal, and İ. Uçum 2016. Fruit and vegetable trade competitiveness of Turkey. XII. Ulusal Tarım Ekonomisi Kongresi. 25-27 May 2016. Isparta.

Box, G. E. P., and G. M. Jenkins 1976. Time Series Analysis Forecasting and Control. Revised Edition, Holden DayInc. California.

Çelik, Z., H. Saçtı, and H. Adanacıoğlu 2019. Trends in foreign trade of cherry and Turkey's comparative advantage. YYU Journal of Agricultural Science 29 (Special Issue): 41-53.

Dickey, D. A., and W. A. Fuller 1981. Likelihood ratio statistics for autoregressive time series with a unit root. Econometrica 49 (4): 1057-1072.

Gül, M., and M. Akpınar 2006. An assessment of developments in fruit production in the world and Turkey. Mediterranean Agricultural Sciences 19 (1): 15-27.

Hinloopen, J., and C. V. Marrewijk 2001. On the empirical distribution of the Balassa index. Weltwirtschaftliches Archiv. 137: 1-35.

Kaygisız, F., and F. H. Sezgin 2017. Forecasting goat milk production in Turkey using artificial neural networks and Box-Jenkins models. Animal Review 4 (3): 45-52.

Ketenci, C. K., and Z. Bayramoğlu 2018. Competition analysis of walnut production in Turkey. Turkish Journal of Agricultural and Natural Sciences 5 (3): 339-347. https://doi.org/10.30910/turkjans.448387
Kurt, R., and S. Karayilmazlar 2019. Mushroom production and projection in Turkey using ARIMA (BoxJenkins). Turkish Journal of Forestry Research 6 (1):72-76

Küçükoflaz, M., A. Akçay, E. Çelik, and S. Sarı̈zkan 2019. Forecasting of red meat and milk prices of Turkey with using the Box-Jenkins models. Journal of The Turkish Veterinary Medical Society 90 (2): 122-131.

Linghong, H., R. Yongmei, and M. Yongqing 2015. Evaluating the peach export competitiveness of Hebei province based on Analytic Hierarchy Process. In: Seventh International Conference on Measuring Technology and Mechatronics Automation (ICMTMA). 13-14 June. Nanchang, China.

Özdemir, B. M., and L. Kösekahyaoğlu 2018. Analysis of Turkey's competitiveness in hazelnut, olive oil and dried apricot using revealed comparative advantage index. ASSAM International Refereed Journal 5 (12): 88-107.

Özer, O. O., and U. İlkdoğan 2013. The world cotton price forecasting by using Box-Jenkins Model. Journal of Tekirdag Agricultural Faculty 10 (2): 13-20.

Özmen, A. 1986. Zaman serisi analizinde Box-Jenkins yöntemi ve banka mevduat tahmininde uygulama denemesi. Doktora tezi. Anadolu Ünivesitesi Sosyal Bilimler Enstitüsü Eskişehir.

Sevüktekin, M., and M. Nargeleçekenler 2010. Ekonometrik Zaman Serileri Analizi - Eviews Uygulamalı. Nobel Yayın Dağıtım. Ankara.

Shalbuzov, N., F. Fikretzade, and R. Huseyn 2020. The international competitiveness of Azerbaijani fruit and vegetable products. Studies in Agricultural Economics 122 (1): 51-55. https://doi.org/10.7896/j.1921

Topuz, B. K., M. Bozoğlu, U. Başer, and N. A. Eroğlu 2018. Forecasting of apricot production of Turkey by using Box-Jenkins Method. Turkish Journal of Forecasting 2 (2): 20-26.

Vollrath, L. T. 1991. A theoretical evaluation of alternative trade intensity measures of revealed comparative advantage. Weltwirtschaftliches Archiv. 127 (2): 265 280 . 